УДК 128:17.023.36

Залужна А. С., Веремейчик С. В.

doi: 10.32620/gch.2018.4.01

\title{
ДУША У ФІЛОСОФСЬКО-ПСИХОЛОГІЧНИХ ПОГЛЯДАХ Г. ЧЕЛПАНОВА
}

Статтю присвячено дослідженню наукових здобутків Г. Челпанова, актуальних на сьогодні не лише у зв'язку з поверненням із забуття ще одного несправедливо замовчуваного імені. Головна тема філософських і психологічних пошуків вітчизняного філософа - тема душі й духовності - надзвичайно важлива для нашого часу.

Ключові слова: душа, психіка, емпіричний паралелізм, матерія, особистість, свідомість, психологія, філософія.

This article is devoted to the philosophical and psychological approaches of G. Chelpanov in the problem field of understanding the essence and nature of the soul. On the analysis basis of the Ukrainian scientist's works, the peculiarity of the connection between the mental and the physical, the psychic and the physical is traced, and the role and interdependence of philosophy and psychology in the study of the problems of the soul are determined in this article.

Keywords: soul, psyche, empirical parallelism, matter, personality, consciousness, psychology, philosophy.

Статья посвящена исследованию научных достижений Г. Челпанова, актуальных на сегодня не только в связи с возвращением из забытья еще одного несправедливо замалчиваемого имени. Главная тема философских и психологических поисков отечественного философа - тема души и духовности - чрезвычайно важна для нашего времени.

Ключевые слова: душа, психика, эмпирический параллелизм, материя, личность, сознание, психология, философия.

Постановка проблеми та актуальність досліджень. У сучасній науковій думці виняткового значення набуває проблема відтворення адекватного змісту культурної спадщини. У цьому контексті неабиякий дослідницький інтерес нині викликають духовно-моральні пошуки представників професійної академічної філософії України другої половини XIX - початку XX ст. У цій площині заслуговує на особливу увагу постать надзвичайно талановитого вченого, філософа, психолога, логіка, педагога, етика Г. Челпанова.

Дослідження наукових здобутків Г. Челпанова актуальне на сьогодні не лише у зв'язку з поверненням із забуття ще одного несправедливо замовчуваного імені. Головна тема філософських і психологічних пошуків вітчизняного філософа - тема душі й духовності - надзвичайно важлива для нашого часу. Вона стає фундаментальною й визначальною на початку третього тисячоліття. I сьогодні вчені знову закликають «повернути Дух із вигнання» й продовжити перервані дослідження духовної діяльності. I саме те, що у світогляді й працях Г. Челпанова значне місце 
посідають проблеми душі й духовності, спонукає сучасних учених неодноразово повертатися до його праць [5].

Важливість розгляду поглядів ученого пояснюється також тим, що його філософські позиції були нерозривно пов'язані 3 психологічними. Саме цей взаємозв'язок є надзвичайно актуальним, оскільки на сьогодні продуктивний діалог між філософією й конкретною наукою постає важливим фактором адекватного осмислення проблеми людини у всій складності, суперечливості, непередбачуваності. А відтак потреба окресленої наукової розвідки зумовлюється науковою й організаційною діяльністю Г. Челпанова, яка крізь призму тісного взаємозв'язку філософського вчення й особливостей становлення психологічної науки кардинально визначає шляхи розвитку сучасної гуманітаристики. У цьому контексті І. Чубаров, коментуючи листи Г. Челпанова до Г. Шпета, зауважує, що Г. Челпанов «був першим справжнім учителем філософії в таких видних представників Срібного віку, як М.О. Бердяєв, С.М. Булгаков, В.В. Зеньківський, О.Ф. Лосєв, В.В. Блонський та ін.» [7, с. 258]. Разом із тим ідеї вітчизняного вченого мали значний вплив на духовноморальні орієнтири становлення академічної філософської думки України й виявилися співзвучними методологічній переорієнтації світової філософії ХX ст. i саме в плані тематизації онтологічних, психологічних та антропологічних питань сприяли становленню професійної філософії та психології.

Аналіз останніх досліджень і публікацій. Вивчення наукової спадщини Г. Челпанова показує, що особистість ученого не була об'єктом серйозної уваги історико-філософської думки. У період розвитку марксизму його погляди піддавалися різкій критиці. До заслуг ученого належало лише заснування Психологічного інституту. У навчальній літературі з історії філософії та історії психології його ім'я до останнього часу навіть не згадується.

Натомість особливий науковий інтерес становлять видані в різні роки спогади учнів Г. Челпанова - П. Блонського, Г. Гордона, В. Зіньківського, О. Лосєва, Н. Рибникова. Водночас заслуговують на увагу опубліковані в останні роки листи Г. Челпанова до Г. Шпета й А. Щербіної. Тільки в 90-і рр. ХХ ст. відбувається повернення до праць Г. Челпанова в контексті обговорення актуальних наукових проблем такими вченими, як Б. Братусь, А. Брушлинський, В. Давидов, В. Зінченко та ін. На сьогодні серед вітчизняних і зарубіжних учених, які вивчали наукові погляди Г. Челпанова, зокрема в контексті досліджень проблем душі й духовності, можна виокремити Г. Аляєва, І. Гладкову, О. Гурєву, Е. Макаренкова, О. Музичок, I. Березінець, Н. Мозгову, Т. Суходуб та ін.

Метою запропонованої статті $\epsilon$ розкриття феномена душі в контексті філософсько-психологічних пошуків професійної академічної думки України кінця XIX - першої половини XX ст. Відтак на основі праць Г. Челпанова спробуємо здійснити експлікацію сутності й природи душі як органічної цілісності душевного життя людини. Для досягнення цієї мети необхідно розв'язати наступні завдання: здійснити аналітичний огляд філософських підходів Г. Челпанова в проблемному полі розкриття сутності категорії «душі»; осмислити особливість взаємозв'язку між душевним і тілесним, психічним і фізичним; визначити роль філософії та психології у 
філософській рефлексії проблематики душі; на підставі висвітлення співвідношення матеріальних $\mathrm{i}$ духовних начал у людині обгрунтувати єдність свідомості й особистісної тотожності.

Виклад основного матеріалу. Г. Челпанов (1862-1936) - український видатний філософ і психолог, автор низки наукових праць і підручників. Його творчий період життя як ученого відбувався в Києві й Москві. Сфера наукових інтересів Г. Челпанова надзвичайно різноманітна: історія філософії, теорія пізнання, онтологія, етика й проблеми логіки.

Високу історичну оцінку отримала його громадська й організаторська діяльність як реформатора філософсько-психологічної освіти. Загальновизнаним був i педагогічний талант Г. Челпанова - професора Київського, а з 1907 до 1923 pp. Московського університету. У найближче коло його наукового спілкування входили такі відомі мислителі, як Н. Грот, П. Ланге, Л. Лопатін, В. Вундт, Е. Тітченер та ін.

Основною ідеєю всіх наукових праць ученого постає пояснення співвідношення тілесного й духовного. Це набуває втілення в його книзі «Мозок і душа», спрямованої на критику матеріалістичних поглядів того часу як таких, що не могли пояснити психічні феномени людини, позаяк: «Справжній стан психології серед інших наук може бути визначено тільки в тому випадку, якщо буде достатньо з'ясовано ставлення між психічними і фізичними явищами» [5, с. 8]. I саме 3 цих позицій вітчизняний філософ відводить особливе місце проблемі дослідження сутності й природи душі.

Властиво, що Г. Челпанов на підставі аналізу філософських поглядів попередніх дослідників виокремлює три основні вчення про природу душі: матеріалістичне (атомістичне), спіритуалістичне (ідеалістичне) і психофізичний монізм (спінозизм) $[10$, с. 23]. Якщо першу концепцію мислитель пов'язує з матеріалістичним ученням Демокріта, згідно з якою тільки матеріальні атоми створюють справжню реальність, оскільки з атомів складається вся дійсність, усе, що існує: і душа, свідомість, думка як рух матеріальних частинок, - то другу концепцію вчений називає ідеалістичною, що постає протилежною доктрині матеріалізму. Згідно з ідеалізмом, основний принцип речей не матеріальні атоми, а щось нематеріальне, духовне. У цьому контексті все у світі наявне складається з духовних елементів, а тому справжня реальність належить тільки духовному.

Третя концепція вчення про душу поєднує в собі протилежності матеріалістичного й ідеалістичного світорозуміння. Цю концепцію в XIX - на початку XX ст. називали «спінозизм», але Г. Челпанов наполягає на терміні «психофізичний монізм». Згідно з цим ученням, матерія не є єдиною субстанцією, якій належить справжня реальність, позаяк існує особлива субстанція, щодо якої духовне й матеріальне $є$ лише проявом.

Розглянуті концепції про душу визнають одну субстанцію й тому називаються моністичними. Безперечно, що філософ у своєму розумінні співвідношення душі i тіла, психічного і тілесного, духовного і матеріального стояв на позиціях дуалізму [10]. Досить часто, розкриваючи те чи інше питання, учений використовує такі поняття, як «дві субстанції», «два світи», «душа й тіло», «матерія та свідомість», 
«різниця між світом фізичним і світом психічним».

Слід відзначити, що саме підхід «емпіричного паралелізму» вчений уважає найбільш достовірним для дослідження проблеми взаємозв'язку душевного i тілесного, психічних i фізичних явищ. У цьому контексті психічний монізм i спіритуалізм розглядається теоріями суперечливими, тоді як матеріалізм - ученням помилковим [10, с. 78]. Таким чином, відстоюючи погляди емпіричного паралелізму, учений акцентує увагу, що головним завданням цього напряму є констатація факту існування співвідношення між духовним і матеріальним, а завданням психофізичного монізму постає пояснення такого співвідношення за допомоги пізнання їх єдності.

Утім, розглядаючи матеріальне й духовне, Г. Челпанов не підтримує думку щодо дослідження їх через призму «відмінних світів». Філософ стверджує тотожність матеріального й психічного саме в контексті розгляду їх у зв'язку зі свідомістю, а саме як якісних їі характеристик. Вітчизняний учений уважає, що ці характеристики становлять той самий зміст із різних боків: зовнішнього і внутрішнього. Натомість для узгодження подальшої думки з цим постулатом необхідно пройти через перепони якості матеріального, зокрема протяжності. У цьому випадку Г. Челпанов знаходить вихід, звертаючись до гносеології. Саме в цій площині можна не ставити акценти на докорінній різниці між матеріальним i духовним, оскільки якісні прояви матеріального, а 3 ними простір, колір визнаються сукупністю наших відчуттів у статусі психічних елементів [1]. «Отже, зрозуміло, що між психічним і фізичним 3 погляду теорії пізнання немає суттєвої різниці; вони зіткані 3 одного й того ж матеріалу, що робить зрозумілою їх тотожність одне з одним, а також і те, що вони становлять два боки одного й того ж явища, що мозок і психічні явища - сутність одного й того самого, що розглядається 3 двох різних поглядів», - справедливо зауважує мислитель [10, с. 283].

Відповідно до концепції «емпіричного паралелізму» душі й тіла, Г. Челпанов розглядає емпіричний метод як умову покращення основного, на його думку, методу в психології - самоспостереження («внутрішній досвід»). При цьому пізнання зовнішнього світу відбувається за допомоги зовнішнього спостереження. Відзначимо, що на формування цих позицій ученого особливий вплив мали погляди В. Вундта i К. Штумпфа (1848-1936).

На основі тісного взаємозв'язку спостереження й процесу умовиводів учений доходить висновку про неможливість обмежити дослідження психічних явищ одним тільки самоспостереженням. Саме у зв'язку з цим Г. Челпанов визнає існування суто емпіричної психології на підставі експериментальних досліджень, які проводяться в галузі фізіології, зоології, психіатрії, а також кримінальної психології, психології народів, психології тварин і т. д. На думку вченого, результати таких досліджень мають практичну важливість i дають цінний матеріал, який необхідно систематизувати, звести до єдності, що в сукупності є завданням «тієї психології, яку ми назвемо загальною, теоретичною або філософською психологією» [11, с. 321].

3 другого боку, Г. Челпанов зауважує, що філософські теорії про душу впливають на пояснення тих чи інших психічних явищ. І цей вплив має характер не випадковий, а необхідний [3]. Саме на основі вищенаведеного вітчизняний учений 
указує на очевидність взаємозв'язку філософії та психології, зокрема в дослідженні сутності поняття «душі». У цьому контексті вчений розуміє філософію як метафізику й гносеологію та зауважує, що будь-які закони душевного життя потрібно розглядати в напрямі метафізичної теорії про природу душі. Неможливо вивчати природу психічних явищ, коли ми зовсім не визнаємо існування душі: тоді, уважає Г. Челпанов, виникає «психологія без душі», без припущення гіпотези душі.

Вилучення гіпотези душі призводить до того, що вивчення психології зводиться до розгляду лише психічних явищ, а завдання психології - до простого опису й класифікації цих явищ. Із таким трактуванням психології, стверджує Г. Челпанов, погодитися не можна: «Опис або класифікація душевних явищ не може здійснюватися без будь-яких керівних ідей» [11, с. 314]. Сам вираз «психологія без душі», відзначає вчений, слід вважати помилковим.

У цьому напрямку досліджень переконливо відстоюється позиція Г. Челпанова щодо неможливості «нічийності» душевних явищ, які завжди мають комусь належати. Адже людина, осмислюючи думки, почуття, бажання, становить щось таке, яке «мислить», «почуває», «має бажання» і яке у філософській традиції називається суб’єктом, «Я», «душею». А відтак душа постає «як середовище, у якому перебувають духовні явища», i визначається вченим як «певна єдність, ...яка комбінує та пов'язує» [11, с. 315].

Звертаючись до розгляду проблеми «душі», Г. Челпанов ставить запитання: якою мірою «душа» як предмет релігійної філософії й метафізики може входити до сфери досліджень психології? Для цього він детально зупиняється на аналізі душі на підставі ідеалістичної та психофізичної концепцій. Так, Г. Челпанов виділяє прихильників субстанціональності (душа витлумачується як субстанція) i представників актуальності (душа - безперервно змінний зв'язок процесів і актів). У цьому випадку Г. Челпанов намагається примирити прихильників як субстанціальності, так і актуальності [4, с. 209].

На підставі цих позицій Г. Челпанов досліджує можливість застосувати поняття субстанції до духовних явищ. Вітчизняний філософ, визначаючи особливість відношення між субстанцією та їі явищами, стверджує: «Під субстанцією ми повинні розуміти той бік явищ, який відрізняється відомою постійністю і який служить основою для явищ, які змінюються» [12, с. 331].

Згідно з поглядами Г. Челпанова, «психічний організм» людини, як і духовний світ, не є простим механічним з'єднанням окремих частин, а постає цілим та єдиним. Цій єдності притаманна «сталість і відносна незмінність», а це є саме ті властивості, які характеризують субстанцію. А відтак, «душа не $є$ механічне складання окремих духовних станів, ...а становить відому організацію, відому єдність, яка є носієм окремих духовних станів» [12, с. 332]. I саме таке поняття душі, указує Г.Челпанов, охоплює іманентність духовним явищам. Тому психологія як наука про душевні явища завжди в той же час постає й наукою про душу. Отже, вітчизняний філософ обгрунтовує, що саме душа є носієм душевних явищ, які, своєю чергою, постають виявленням душі, позаяк дослідження іiї природи та властивостей має бути основним завданням психології. 
Утім, вивчення психології не може зводитися тільки до простого опису й класифікації психічних явищ, а потребує гносеологічного аналізу основних понять психічних процесів та оперування філософськими категоріями «субстанції», «причини», «взаємодії», «відмінності», позаяк «навіть «чистий досвід потребує філософської рефлексії, чому він називається чистим» [11, с. 316]. Тобто для того щоб вийти за межі безпосереднього досвіду, необхідно використовувати гносеологічно оброблені поняття, які належать до компетенції філософії. Називаючи філософію наукою про дух й редукуючи ії основне питання до визначення ролі духу у світовому розвитку, Г. Челпанов слушно зауважує, що як «фізика, хімія і механіка необхідні для вивчення основних властивостей матерії, так і психологія сприяє виясненню основних властивостей духу» [11, с. 317]. Тому кожний психолог повинен прагнути бути філософом, а психологія повинна стати філософською наукою й такий зв'язок із філософією є природнім і необхідним.

В аспекті співвідношення психічного й фізичного в праці «Душа та мозок» Г. Челпанов піднімає проблему особистості. Мислитель уважає, що завдяки зусиллям волі здійснюється усвідомлення людиною свого внутрішнього світу й підпорядкування тіла моєму «Я». I саме таке уявлення цілісного «Я»в синтезуванні уявлень про внутрішній світ і власного тіла й постає в розумінні вітчизняного філософа особистістю [4]. Він показує, що особистість у жодному разі не може бути простим поєднанням окремих явищ і станів психіки, оскільки вони забезпечуються існуванням цілісності душевного життя, яка і є основою особистості.

Варто зауважити, що під час подальших наукових досліджень Г. Челпанов доходить висновку, що під душею слід мати на увазі інтегративний принцип, який дозволяє пояснити феномени єдності свідомості й тотожності особистості людини. Разом із тим учений пояснює положення про тотожність особистості, яку в жодному разі не можна розуміти в абсолютному сенсі. У різні моменти життя існують різні психічні процеси, емоційні стани, які $\epsilon$ плинними й змінними. Тотожність особистісного «Я» в площині безперервності багатоманітних уявлень, духовних станів, які «змінюють один одного і для різних моментів життя є різними», утім, завдяки «цій безперервності і встановлюється тотожність нашого «Я». Має бути те, що утримує цю безперервність, вміщує в себе» $[10$, с. 303]. Саме наше «Я» $\epsilon$ постійним у швидкоплинності душевних явищ і при всьому багатстві розмаїття й змінності психічного життя залишається тотожним самому собі. Фундаментальним проявом окресленого принципу постає почуття відповідальності за свої вчинки, здійснені за період свого життя.

Властиво, що феномен душі й особливість іï співвідношення 3 психічним, актуалізовані Г. Челпановим, не втрачають інтересу i в сучасних наукових дослідженнях. Так, російський психолог Б. Братусь звертає увагу на складність будови душі, у свій час так грунтовно концептуалізованої вітизняним філософом. Він наголошує на необхідності поєднання в психології наукового дослідження психіки людини з метафізичними тлумаченнями іiі вічності та Божественного походження, оскільки «дослідження психіки повинні слугувати розумінню умов розкриття Божественного призначення душі, а слова й повчання про душу повинні мати на увазі 
розуміння специфіки й законів психічного улаштування людини» [2, с. 41].

Висновки та перспективи подальших досліджень. Таким чином, дослідження наукової спадщини Г. Челпанова засвідчує визначальну роль філософії в постановці й вирішенні психологічних проблем, зумовлюючи вихід психології на якісно новий рівень, який до того часу був властивий тільки філософії. Запропонований вітчизняним мислителем термін «філософія психології» закладає істотне підгрунтя для становлення нового виміру філософської й психологічної науки, дистанціюючи їх за теоретичні межі й виводячи в простір практичної реалізації.

Здійснивши аналіз розвитку наукової думки від античного матеріалізму до теоретичних побудов філософів і психологів кінця ХІХ ст., Г. Челпанов доходить висновку, що душа розуміється як певна єдність і органічна цілісність душевного життя людини, як середовище, у якому перебувають духовні явища. А відтак, під душею вчений розуміє відносно стійку сутність людини, що уможливлює в будь-яких негараздах відчувати себе самою собою, бути моральною й шукати істину.

Водночас слід зазначити, що тематизовані вітчизняним ученим питання антропологічних засад філософського знання в проблемному полі феномена душі й особливості їі співвідношення з психічним потребують подальших наукових розвідок, визначаючи значною мірою шляхи розвитку сучасної гуманітаристики.

\section{Література:}

1. Березінець I. B. Метафізика як стрижень наукової концепції Г. Челпанова // Актуальні проблеми філософії та соціології. 2016. Вип. 12. С. 15-19.

2. Братусь Б. С. Психология - наука о психике или учение о душе? // Человек. 2000. №4. С. 30 41.

3. Гладкова И. В. Становление русской психологии как самостоятельной науки: позиция Г. И. Челпанова // Известия Уральского федерального университета. Сер. 3, Общественные науки. 2012. № 4 (109). С. 158-165.

4. Гурьева О.С. Природа «души» и возможности ее познания (на примере работы Г. И. Челпанова» Мозг и душа») // Зб. доповідей за матеріалами міжнародної конференції 20-21 квітня 2012 р. Маріуполь : ДВНЗ «Приазов. держ. техн. ун-т», 2012. С. 208-211.

5. Зінченко В. П. Культурно-історична психологія: досвід ампліфікації // Питання психології. 1993. № 4. C. 6-19.

6. Лопатина Л. М. «Понятие о душе по данным внутреннего опыта» // Вопросы философии и психологии. 1896. Кн.32 (XXXII). С. 264-298.

7. Письма к Густаву Шпету Г. И. Челпанова, Л. И. Шестова, Б. В. Яковенко, Р. О. Якобсона и др. / Публикация, предисловие и комментарии И. Чубарова // Логос. 1992. № 3. С. 243-263.

8. Суходуб Т. Д. Философская позиция Г. И. Челпанова: в оценках мыслителей Серебряного века и современных // Зб. доповідей за матеріалами міжнародної конференції 20-21 квітня 2012 р. Маріуполь : ДВНЗ «Приазов. держ. техн. ун-т», 2012. С. 185-189.

9. Франк С. Душа человека // Предмет знания. Душа человека. Минск : Харвест, М. : АСТ, 2000. C. 633-690.

10. Челпанов Г. И. Мозг и душа. Критика материализма и очерк современных учений о душе. 5е изд. М., 1912.319 с.

11. Челпанов Г.И. Об отношении психологии к философии // Вопросы философии и психологии. 1907. Кн. IV (89). С. 309-323.

12. Челпанов Г. И. Очерк современных учений о душе // Вопросы философии и психологии. 1900. Кн. 52 (II) C. 287-333. 


\section{Alla Zaluzhna, Serhiy Veremeychik \\ SOUL IN PHILOSOPHICAL AND PSYCHOLOGICAL VIEWS OF G. CHELPANOV}

This article is devoted to the philosophical and psychological approaches of G. Chelpanov in the problem field of understanding the essence and nature of the soul. On the analysis basis of the Ukrainian scientist's works, the peculiarity of the connection between the mental and the physical, the psychic and the physical is traced, and the role and interdependence of philosophy and psychology in the study of the problems of the soul are determined in this article. The peculiarity of the reorientation of the national philosophical thought to the questions of anthropological and ontological nature, which were consistent with the methodological shift of the world philosophy of the twentieth century are investigated.

The peculiarity of psychology as philosophical and experimental science, the main task of which the thinker reduces to the definition of the laws of mental phenomena and mental life is highlighted. The phenomenon of the soul is elaborated from the position of G. Chelpanov's empirical parallelism. In this context, the soul is regarded as a substantive (spiritual) basis of personality, a substance, a carrier of all spiritual states, which determines their combination into a single integrity and provides personal self-identity. After all, the personality can not in any case be a simple combination of individual phenomena and states of the psyche, because they are ensured by the existence of the integrity of mental life, which is the basis of human existence.

The article substantiates that the strengthening in philosophical and psychological studies in the problem of the soul leads to new variants of the interaction of science and religion and an appeal to centuries-old religious and moral experience. The article concludes that the conceptualization of G. Chelpanov's dominant soul in his «philosophy of psychology» provides an essential basis for the formation of a new level of psychological science within the framework of the relationship between psychology and philosophy and largely determines the ways of development of contemporary humanitarianism.

Keywords: soul, psyche, empirical parallelism, matter, personality, consciousness, psychology, philosophy. 


\section{Алла Залужна, Сергій Веремейчик}

\section{ДУША У ФІЛОСОФСЬКО-ПСИХОЛОГІЧНИХ ПОГЛЯДАХ Г. ЧЕЛПАНОВА}

Дослідження наукових здобутків Г. Челпанова актуальне на сьогодні не лише у зв'язку з поверненням із забуття ще одного несправедливо замовчуваного імені. Головна тема філософських і психологічних пошуків вітчизняного філософа - тема душі й духовності - надзвичайно важлива для нашого часу. Вона стає фундаментальною й визначальною на початку третього тисячоліття. I сьогодні вчені знову закликають «повернути Дух з вигнання» й продовжити перервані дослідження духовної діяльності. I саме те, що у світогляді та працях Г. Челпанова значне місце посідають проблеми душі й духовності, спонукає сучасних учених неодноразово повертатися до його праць. Метою запропонованої статті $\epsilon$ розкриття феномена душі в контексті філософсько-психологічних пошуків професійної академічної думки України кінця XIX - першої половини XX ст. А відтак, на основі праць Г. Челпанова спробуємо здійснити експлікацію сутності та природи душі як органічної цілісності душевного життя людини. Для досягнення цієї мети необхідно розв'язати наступні завдання: здійснити аналітичний огляд філософських підходів Г. Челпанова в проблемному полі розкриття сутності категорії «душі»; осмислити особливість взаємозв'язку між душевним і тілесним, психічним і фізичним; визначити роль філософії та психології у філософській рефлексії проблематики душі; на основі висвітлення співвідношення матеріальних і духовних начал у людині обгрунтувати єдність свідомості й особистісної тотожності. Дослідження наукової спадщини Г. Челпанова засвідчує визначальне значення філософії в постановці й вирішенні психологічних проблем, зумовлюючи вихід психології на якісно новий рівень, який до того часу був властивий тільки для філософії. Запропонований вітчизняним мислителем термін «філософія психології» закладає істотне підгрунтя для становлення нового виміру філософської й психологічної науки, дистанціюючи їх за теоретичні межі й виводячи в простір практичної реалізації. Здійснивши аналіз розвитку наукової думки від античного матеріалізму до теоретичних побудов філософів і психологів кінця XIX ст., Г. Челпанов доходить висновку, що душа розуміється як певна єдність і органічна цілісності душевного життя людини, як середовище, у якому перебувають духовні явища. А відтак, під душею вчений розуміє відносно стійку сутність людини, що уможливлює в будь-яких негараздах відчувати себе самою собою, бути моральною й шукати істину.

Ключові слова: душа, психіка, емпіричний паралелізм, матерія, особистість, свідомість, психологія, філософія. 
Zaluzhna Alla Evgenivna, Doctor of Philosophical Science, Professor, Professor of the department of Philosophy of University of Water and Environmental Engineering, Rivne.

Залужна Алла Євгенівна, доктор філософських наук, професор, професор кафедри філософії Національного університету водного господарства та природокористування, м. Рівне.

e-mail: zaluzhna@yandex.ru

Veremeychyk Serhiy Volodymyrovych, Post-graduate Student of the department of Philosophy of University of Water and Environmental Engineering, Rivne.

Веремейчук Сергій Володимирович, здобувач кафедри філософії Національного університету водного господарства та природокористування, м. Рівне.

Надійшла до редакції 29.11.2018. Розглянута на редколегії 18.12.2018.

\section{Рецензенти:}

Доктор філософських наук, професор кафедри філософії Національного аерокосмічного університету ім. М.Є. Жуковського «ХАІ» Кузнєцов А.Ю.

Доктор філософських наук, професор, декан гуманітарного факультету Національного аерокосмічного університету ім. М.С. Жуковського «ХАI» Копилов В.О. 